\title{
KUKA VOISI VASTUSTAA OPETUKSEN LAATUA?
}

\section{Tutkijatapaamisen jälkimaininkeja}

I stumme junassa matkalla kohti kotia. Taakse jää Jyväskylä, jossa olemme Aikuiskasvatuksen tutkijatapaamisessa käyneet monia mielenkiintoisia keskusteluja. Väsymys on jo valtaamassa mielen, mutta kriittiset kysymykset saavat meidät terästäytymään.

Keskustelu porautuu ensin vireillä olevaan korkeakoulujen tutkinnonuudistukseen, jossa yliopistoväki tekee kiireen ja epätietoisuuden vallassa ydinaineanalyysejä ja suunnittelee vetovoimaisia maisteriohjelmia. On erilaisia käsityksiä siitä, mikä on kasvatus- tai aikuiskasvatustieteen "ydinainesta“". On myös epäilty, että harmonisoinnin nimissä tutkintoja saatetaan karsia, jolloin tutkinnoista lentäisi ensiksi yli laidan yhteiskunnalliseen ajatteluun johdattava aines. Yliopistojen käytävillä ja kokoushuoneissa kuulee tyytymättömiä äänenpainoja, mutta silti olemme kaikki joukolla kiltisti viemässä eteenpäin uudistusta, joka johtaa EU-maiden koulutusjärjestelmien harmonisointiin. Tämä on suunta, vaikka EU-kansanäänestyksen aikoihin vielä korostettiin, että jäsenmaiden koulutusjärjestelmä kuuluu kansallisen päätöksenteon piiriin.

Keskustelumme siirtyy yliopistotkin vallanneeseen tulosajatteluun. Opetuksen laatu ja laatujärjestelmät saa meidät melkein kiihtymään. Alamme löytää aiheeseen niin paljon kriittisiä näkökulmia, että on pakko kaivaa esiin kynä ja lehtiö.

Juna kiitää kohti etelää ja mind map -piirrokseemme kertyy yhä useampia haarakkeita. Heittelemme kysymyksiä opetuksen laadusta, kerimme esiin näkökulmia. Miksi tutkimusseminaareissa niin harvoin asetetaan ylhäältä tarjottuja itsestäänselvyyksiä kyseenalaisiksi - tai ainakaan niiden virallisissa sessioissa?

Opetuksen laatua koskeva diskurssipilvi on leijunut ympärillemme jo vuosia. Silti siihen on vaikea saada otetta. Se on hallinnon lanseeraama ohjelma, joka on valjastanut yksiköt kilpailemaan keskenään. Kuka voisi vastustaa opetuksen laatua?

\section{MIKÄ JA MILLAINEN LAATU?}

Laatu voi viitata jonkin asian ominaislaatuun, siihen, miten tunnistamme erilaiset asiat yhteyksissään. Esimerkiksi opetus ja oppiminen on toimintana erilaista kuin teollinen tuotanto. Käsitettä voidaan käyttää myös adjektiivin tavoin viittaamaan laadukkaaseen, jonka vastakohtana on laaduton. Opetuksen ei haluta olevan ainakaan laadutonta. Millaista laatua tavoitellaan?

Zen ja moottoripyörän kunnossapito -kirjan kirjoittaja Robert Pirsig puhuu staattisesta ja dynaamisesta laadusta. Staattinen laatu viittaa tavoiteltavaan standardiin ja minimitasoon. Tällaista laatua voidaan myös mitata. Dynaaminen laatu taas viittaa ennakoimattomuuteen, luovuuteen ja tapahtumiseen. Sen saattaminen mitattavaan muotoon on hankalaa.

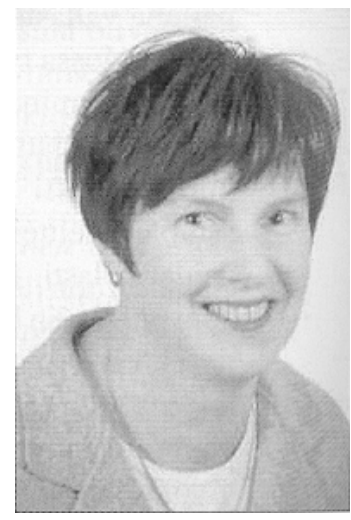

Marjo Vuorikoski

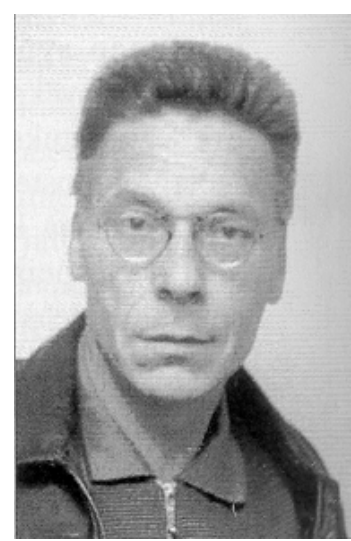

Jussi Onnismaa
Koulutuksen laatua pyritään varmistamaan samantyyppisen staattisen ajattelun mukaan kuin monilla muillakin aloilla. Yhteiskunnassa vallitseva mittaamisen ja järjestelmien luomisen vimma on johtanut siihen, että myös ihmisten vuorovaikutukseen perustuvaa toimintaa arvioidaan samaan tapaan kuin tuotteita tehtaan liukuhihnoilla - noudatetaan tuotannon logiikkaa vaikka kyse on elävistä ihmisistä.

Opetus on ihmisten opettamista. Opettajatkin ovat ihmisiä, naisia ja miehiä, eivätkä mitään opetuskoneita. Opetus ja ohjaus tulisi nähdä dynaamisina prosesseina, joissa luovuus, liikkuvuus ja ennakoimattoman mahdollisuus voitaisiin hyväk- 
syä. Mallit ja mittaamisen järjestelmät voivat pakottaa opetuksen standardeihin ja ideaaleihin, jotka ovat ihmisen kasvulle vieraita. Ne voivat toimia oppimisen esteinä. Laatu- ja standardiajattelu opetus- ja ohjaustyössä luo myös tarpeettoman järki-tunne-dikotomian, vaikka järjen vastakohta on järjettömyys ja tunteen vastakohta tunteettomuus. Kontrollifantasioiden sijasta nyt tarvittaisiin mahdollisuuden tajua.

\section{KENEN LAATU?}

Piirrokseemme ilmestyy teemoja ja avainsanoja, jotka liittyvät valtaan. Ihmettelemme, miksi opetukseen liittyvät valtakysymykset niin usein unohdetaan. Ehkä ne on piilotettu niin hyvin, että käytännön toimijoiden on vaikea havaita ympärilleen kietoutuneita vallan seittejä? Tosin Foucault'n valta-analyyseihin pohjaavat koulutustutkimukset ovat alkaneet raotella niitä verhoja, joiden takana piiloisen vallan muodot lymyävät ja näkymättömällä tavallaan ohjailevat opiskelijoita ja opettajia.

Tunnelma alkaa tiivistyä, kun pääsemme kätketyn vallan muotoihin. Muu junanvaunu ei jaa innostustamme, vaan muut matkustajat torkkuvat tuoleissaan. Voi olla, että innostunut puheensorinamme jopa häiritsee heitä. Paneudumme siihen, kenen näkökulmasta opetuksen laatua yleensä pohditaan.

"Asiakkaan" etuhan tietysti on kyseessä! Näin sanotaan silloinkin, kun on kyse puhujan omista intresseistä, oman aseman parantamisesta tai puolustamisesta. Mitä etuja laadun kehittämisestä mahdollisesti on kouluttajille itselleen? Mitä haittaa siitä mahdollisesti on?

Puhe laadusta on myös retoriikkaa. Opettajien omiin kokemuksiin ja käsityksiin pohjaava kieli korvautuu työn tarkoituksen kannalta vieraalla uudiskielellä. Laatu on yksi koulutuksen kentälle työntyneistä mantroista, joita hoetaan ehkä tietämättä, mitä kaikkea niihin sisältyy. Elämme is- kusanojen aikaa. Aikaisemmat puheet oikeudenmukaisuudesta, tasa-arvosta ja kansalaisuudesta koulutuspuheessa ovat muuttuneet käsitteiksi, joiden sisältö on hyvin epämääräinen. Silti niistä näyttää tulevan totta, kun niitä tarpeeksi kauan toistellaan. Laatu-puheen lisäksi viime vuosina korvissamme soineita koulutuskentän iskusanoja ovat asiakkuus, joustavuus, itseohjautuvuus, elinikäinen oppiminen....

Kun ylhäältä päin syötetään samaa iskulausetta riittävän monta kertaa, sen odotetaan saavan aikaan oikeanlaisen reaktion Pavlovin koirien tapaan. Paras työntekijä on vailla muistia tai "muutosvastarintaa“" ja osaa reagoida vikkelästi milloin mihinkin. Hän on aina valmis ottamaan vastaan uutta, kyselemättä mihin katosivat edellisen vuoden iskulauseet, saati sellainen kieli, joka viittaisi työn tarkoitukseen ja tavoitteisiin. Foucault'n termi vastamuisti muistuttaa siitä, että kollegoiden yhteinen keskustelu voi valtauttaa ja auttaa muistamaan uudelleen sen, mikä on jo lähes painunut unohduksiin.

Iskusanat ovat puheverhoja, jotka estävät kriittisen suhtautumisen. Esimerkiksi puhe sukupuolten tasa-arvosta suomalaisessa yhteiskunnassa estää näkemästä sukupuolten epätasa-arvoa. Illuusio tasa-arvosta johtaa siihen, ettei asiaan suhtauduta riittävän vakavasti eikä koota tutkimustietoa koulutuksen kehittämisen pohjaksi.

Puhe laadusta on retorinen keino suostutella meidät hyväksymään käsitykset laadun kehittämisen tarpeellisuudesta. Laatuajattelu on kuitenkin tuotu hallinnosta. Se on osa johtamisjärjestelmää. Yksiköitä ja opettajia houkutellaan opetuksen kehittämiseen, mutta samalla myös kilpailemaan keskenään. Onko tavoitteena vain saada yksiköt ja opettajat juoksemaan entistä kovempaa erilaisten laatupalkintojen toivossa?

Marjo Vuorikoski ja Jussi Onnismaa 